\title{
Investigation of Seasonal Total Phenolics and Pigments in Chara vulgaris
}

\author{
Aysel Sivaci (Corresponding author) \\ Department of Biology, Art and Science Faculty, Adiyaman University, Adiyaman, Turkey
}

Tel: 416-223-1775 E-mail: asivaci@gmail.com

\begin{abstract}
Sevcan Duman
Graduate School of Sciences, Adiyaman University, Adiyaman, Turkey

Tel: 416-223-1775 E-mail:sevcanduman3@hotmail.com
\end{abstract}

Sevran Eroğlu

Graduate School of Sciences, Adiyaman University, Adiyaman, Turkey

Tel: 416-223-1775 E-mail:sevraneroglu@yandex.com

\section{E.Rıdvan Sivaci}

Department of Biology, Art and Science Faculty, Adiyaman University, Adiyaman, Turkey

Tel: 416-223-1775Ｅ-mail:rsivacii@gmail.com

Received: February 14, 2015 Accepted: March 9, 2015

doi:10.5296/jbls.v6i2.7096 URL: http://dx.doi.org/10.5296/jbls.v6i2.7096

\begin{abstract}
In this study, Chara vulgaris samples were taken from Gölbaşı Lake/Adıyaman at different times (October, February, April, June). Total phenolic and pigment contents of these samples were examined. It was determined that total phenolic and pigment contents (chlorophyll a, chlorophyll $\mathrm{b}$, and carotenoids) showed seasonal differences. It was detected that chlorophyll a, chlorophyll b, and carotenoids were high in June, and low in April. In addition, phenolic compounds were found to be high in February, and low in April.
\end{abstract}

Keywords: Chara vulgaris, Phenolics, Photosynthetic pigments, Seasonal cycle 


\section{Introduction}

Phenolic compounds are secondary metabolites produced by plants They have various functions such as protection against pathogens and ultraviolet radiation, mechanical support, and attraction of pollinating animals (Bravo, 1998; Parr \& Bolwell, 2000). Many phenolic compounds have been determined to have health benefits (Houston, 2005; Zafar et al., 2013). These compounds vary depending on environmental conditions and stress factors. In many studies, it was reported that phenolic compounds were synthesized in aquatic plants, and the amount of these compounds changed depending on the season and environmental conditions (Spencer \& Ksander, 1994; Gross et al., 1996; Bauer et al., 2009).

Underwater vegetation is more exposed to seasonal changes from external factors especially in areas exposed to tides and wave motions, and in coastal regions where water loss is sudden (Whitfield et al., 2007). Chara is a wild genus spread over many natural waters. Species of this genus can intake nutrients very effectively owing to their rhizoids. Charophytes groups, which are known as water meadows, intake some chemicals known as nutrients (i.e. phosphate, nitrate, ammoniac etc.) and use these nutrients in photosynthesis process. If they reach adequate biomass in aquatic systems, they could affect the food chain in aquatic systems (Kufel \& Kufel, 2002). Chara is a good hiding place for fry, a good habitat for laying eggs and important for protection of environmental balance (Denike \& Geiger, 1974).

As it was suggested in numerous studies, many aquatic plants(as in Chara spp.) intake heavy metals in the system while intaking substances required for photosynthesis such as phosphate, nitrate, ammoniac etc. Thus, they undertake an important role by removing heavy metals in aquatic systems (Kamal et al., 2004; Narain et al., 2011; Shaikh \& Bhosle, 2011). Moreover, Mahajan \& Kaushal (2013) were determined that C. vulgaris could remove congo red from aquatic solutions. Likewise, Shaikh \& Bhosle (2011) reported that Chara and Hydrilla species could remove chromium in aquatic systems.

In aquatic habitats, a continuous macrophyte composition is essential for the system to sustain its stability by balancing its chemical composition. Contaminating factors must be removed by filtration from the environment to have usable water, which includes many nutrients such as phosphate, nitrate, ammoniac, silicium magnesium, and nitrate. For this purpose the continuity of macrophytes is obligatory in the system. Therefore, it is important to detect the changes of pigment and phenolics of Chara, which are depended on environmental differences that are caused by seasonal changes. To achieve this goal, seasonal changes in pigment (chlorophyll a, chlorophyll $\mathrm{b}$ and carotenoids) and phenolic contents of $C$. vulgaris, which was collected from Lake Gölbaşı, were determined.

\section{Materials and Methods}

Chara vulgaris samples were collected (in October, February, April, June) from Lake Gölbaş1/Adıyaman,Turkey between 2011-2012. Pigment contents were extracted in acetone according to the method described by De Kok \& Graham (1989). Amount of pigments were determined as it was described by Lichtenthaler \& Wellburn (1983). Total phenolic compounds of the samples were determined depending on folin reactive and standard gallic 


\section{Macrothink}

acid equivalence (Slinkard \& Singleton, 1977; Chandler \& Dodds, 1983).

\subsection{Statistical Analysis}

The results obtained from three replications were evaluated using the SPSS 15.0 program Duncan's test was used for significance control $(\mathrm{P}<0.05)$.

\section{Results and Discussion}

It was found that photosynthetic pigments in $C$. vulgaris varied according to season. It was

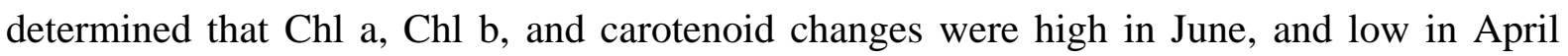
(Figures 1, 2, 3).

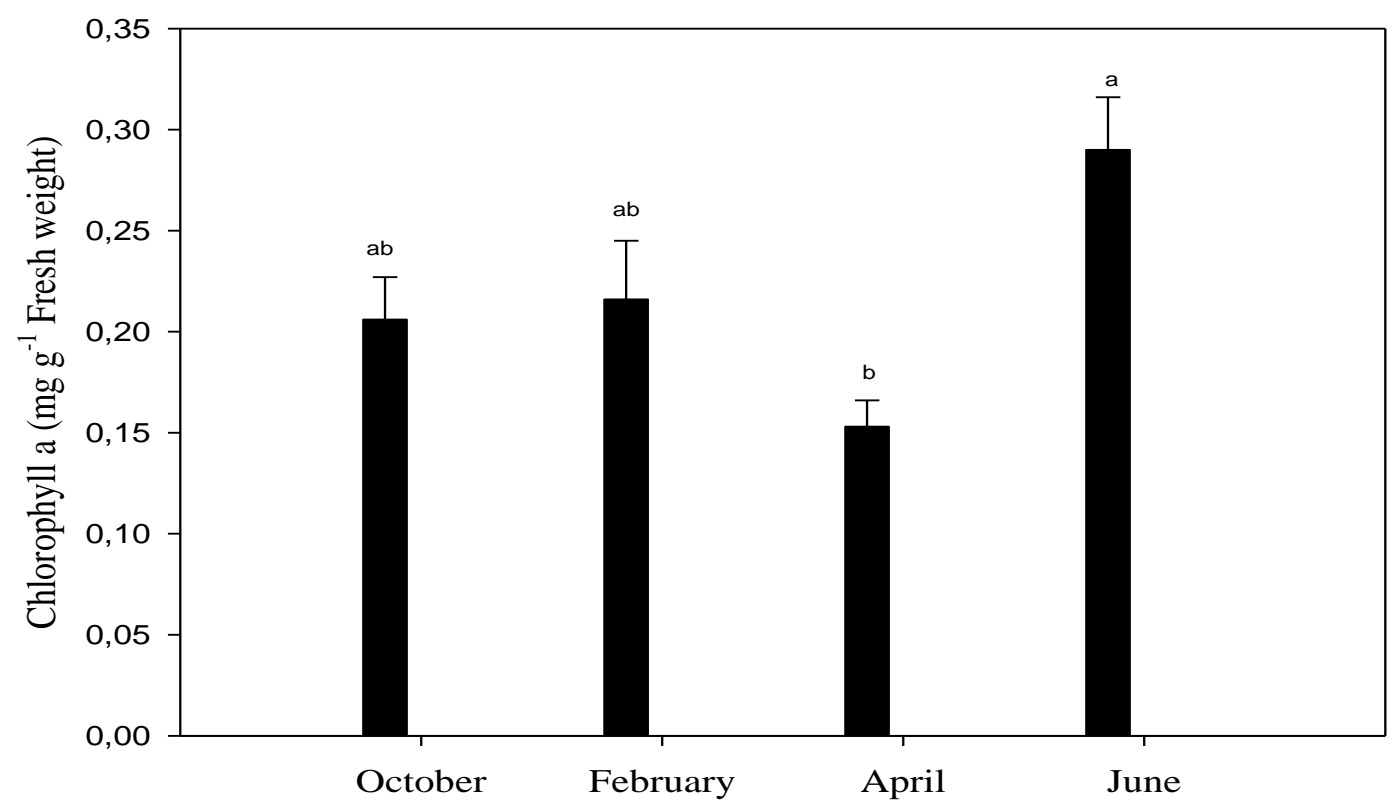

Fig. 1. Seasonal chlorophyll a changes in Chara vulgaris

(Data followed with different letters are significantly different from each other $(\mathrm{p}<0.05)$ according to Duncan's test).

In studies on macrophyte species, Pilon \& Santamaría (2001) detected that chlorophyll concentrations change according to species and months. When Callitriche obtusangula is evaluated in terms of total chlorophyll concentration, it was reported as a species which alters seasonally, and chlorophyll concentrations were found to be highest in March and July, and lowest in May. Anton \& Putt (1988) determined the photosynthetic productivity of Chara vulgaris L., which was maximum for submersed macrophytes in early summer. As described in the studies above, in this study pigment levels were also found to be high in early summer (June) (Figures 1, 2, 3). 


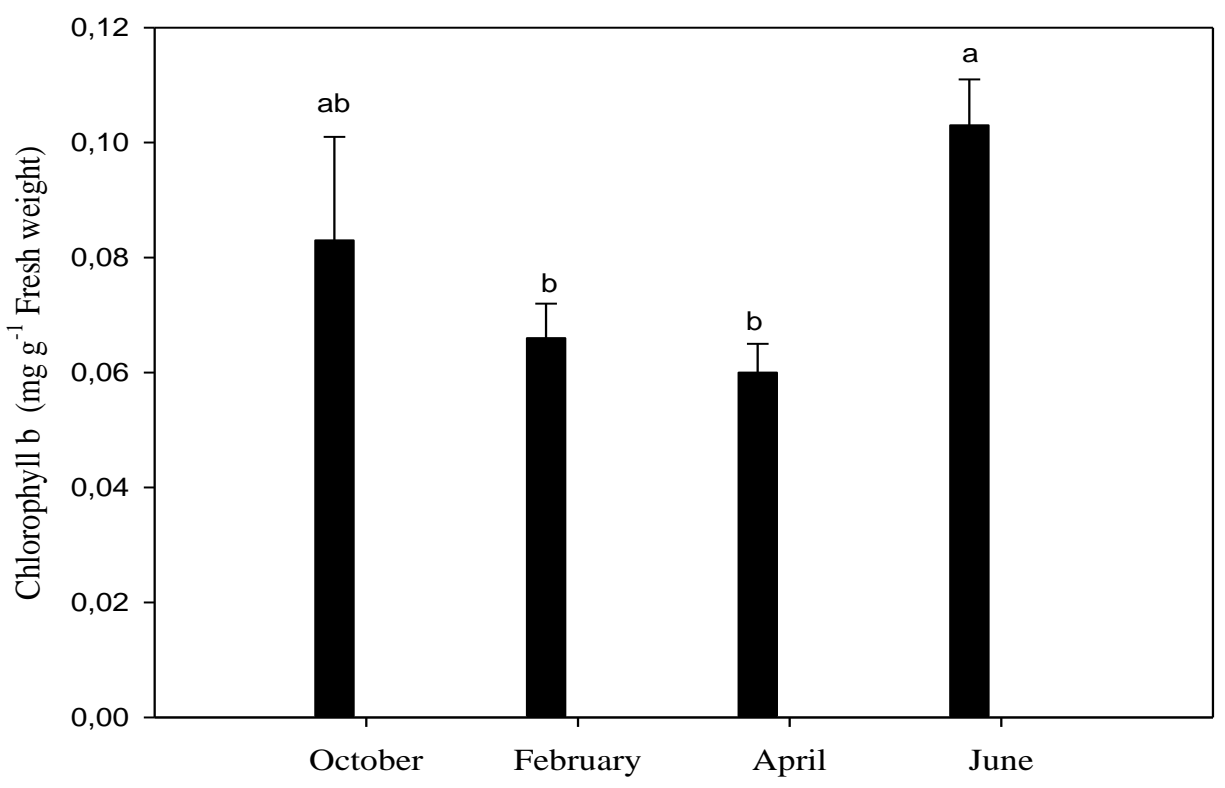

Fig. 2. Seasonal chlorophyll b changes in Chara vulgaris

(Data followed with different letters are significantly different from each other $(\mathrm{p}<0.05)$ according to Duncan's test).

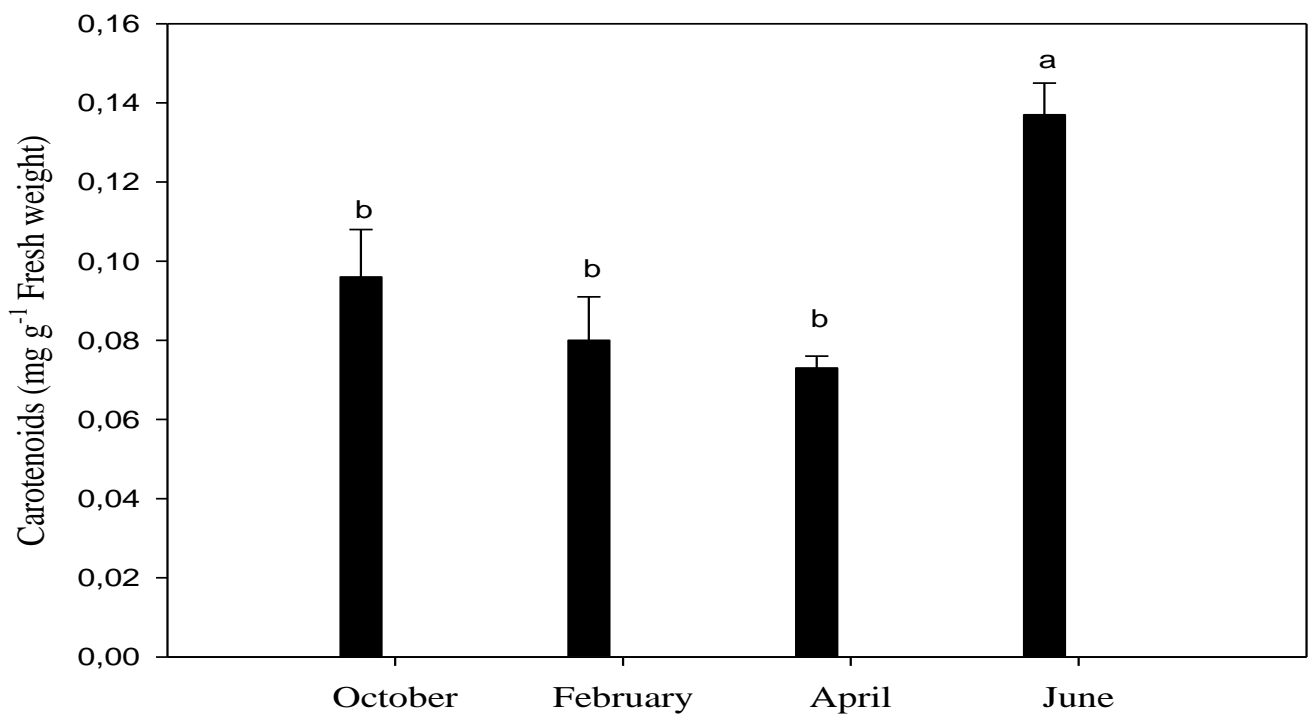

Fig. 3. Seasonal carotenoid changes in Chara vulgaris

(Data followed with different letters are significantly different from each other $(\mathrm{p}<0.05)$ according to Duncan's test). 


\section{Macrothink}

In addition, it was detected that phenolic compounds change depending on months. It was determined that phenolic compounds were at highest concentration in February $(0.454 \mu \mathrm{g}$ $\left.\mathrm{mg}^{-1}\right)$, and at lowest concentration in April $\left(0.158 \mu \mathrm{g} \mathrm{mg}^{-1}\right)$. It was also detected that phenolic levels in June are close to that are in February $\left(0.440 \mu \mathrm{g} \mathrm{mg}^{-1}\right)$ (Figure 4). It was determined that phenolic compound production of plants changes depending on biotic and abiotic factors. Also it was shown that the differences in phenolic compound may occur depending on plant species, genetic characteristics and plant type (Smolders et al., 2000; Boege, 2005; Cronin \& Lodge, 2003; Li et al., 2010). In another study, it was determined that phenolic compounds in aquatic plants and filamentous algae change depending on plant organ and season but doesn't change depending on the age of the plant (Pip, 1992). Our findings are in agreement with the study described above, which suggested that phenolics changed depending on the season.

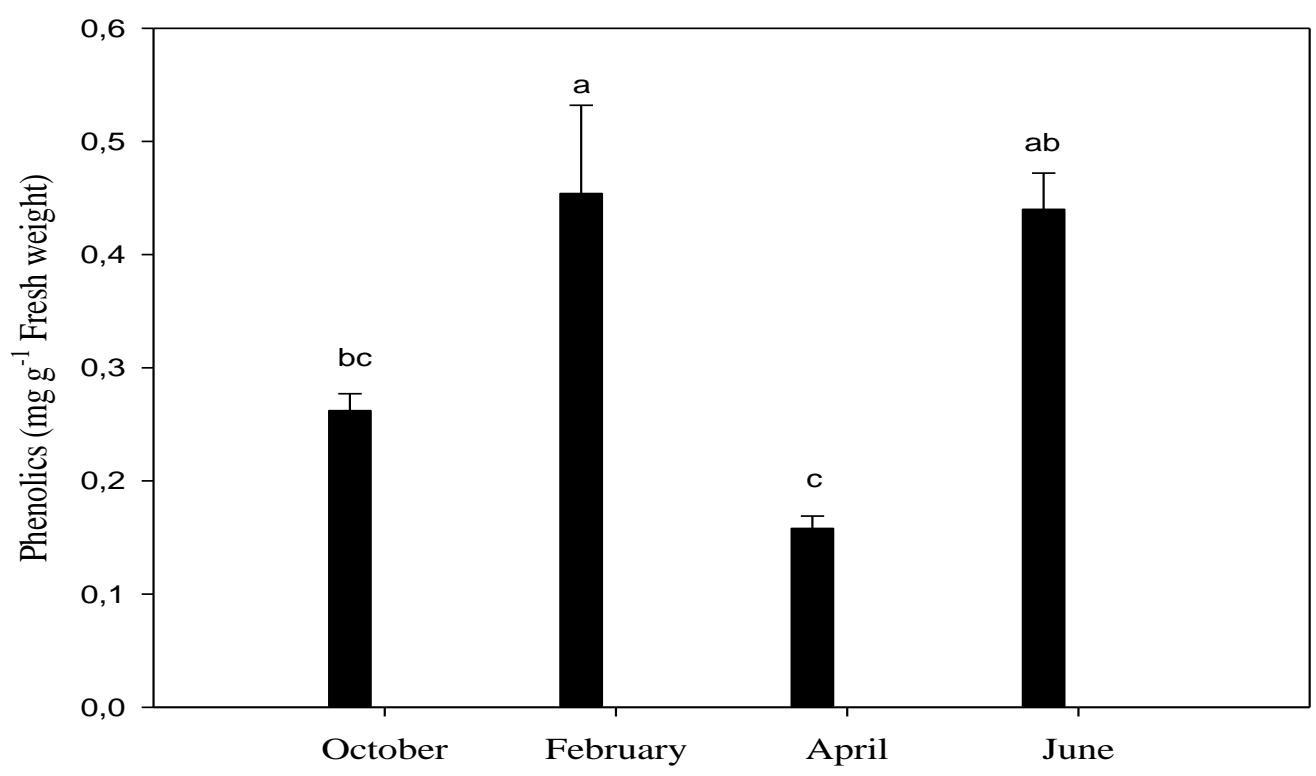

Fig. 4. Seasonal total phenolic compounds in Chara vulgaris

(Data followed with different letters are significantly different from each other $(\mathrm{p}<0.05)$ according to Duncan's test).

\section{Conclusion}

Determining of seasonal photosynthetic pigments and phenolics synthesized for defense in Chara vulgaris may provide information regarding to the continuity and metabolic responses of this species depending on environmental conditions that may change in aquatic systems.

\section{References}

Anton, H. R., Putt, D. A. (1988). Factors Influencing Photosynthetic Productivity of Chara vulgaris L. in a Moderately Productive Hardwater Lake. Journal of Freshwater Ecology, 4, 411-418. http://dx.doi.org/10.1080/02705060.1988.9665192 
Bauer, N., Blaschke, U., Beutler, E., Gross, E.M., Jenett-Siems, K., Siems, K., Hilt, S. (2009). Seasonal and interannual dynamics of polyphenols in Myriophyllum verticillatum and their allelopathic activity on Anabaena variabilis. Aquatic Botany, 91, 110-116. http://dx.doi.org/10.1016/j.aquabot.2009.03.005

Boege, K. (2005). Influence of plant ontogeny on compensation to leaf damage. American Journal of Botany, 92, 1632-1640. http://dx.doi.org/10.3732/ajb.92.10.1632

Bravo, L. (1998). Polyphenols: chemistry, dietary sources, metabolism, and nutritional significance. Nutr Rev. 56, 317-333. http://dx.doi.org/10.1111/j.1753-4887.1998.tb01670.x

Chandler, S. F., Dodds, J. H. (1983). The effect of phosphate, nitrogen and sucrose on the production of phenolics and solasidine in callus cultures of Solanum lacinitum. Plant Cell Reports., 2, 205-208. http://dx.doi.org/10.1007/BF00270105

Cronin, G., Lodge, D. M. (2003). Effects of light and nutrient availability on the growth,allocation, carbon/nitrogen balance, phenolic chemistry, and resistance to herbivory of two freshwater macrophytes. Oecologia, 137, 32-41. http://dx.doi.org/10.1007/s00442-003-1315-3

De Kok, L. J., Graham. M. (1989). Levels of pigments, soluble proteins, amino acids and sulfhydryl compounds in foliar tissue of Arabidopsis thaliana during dark-induced and natural senescence. Plant Physiology and Biochemistry, 27, 203-209.

Denike, T. J., Geiger, R. W. (1974). The utilization of chara in water management. Journal of Aquatic Plant Management, $\quad 12, \quad$ 18-20. http://apms.org/wp/wp-content/uploads/2012/10/v12p18.pdf

Gross, E. M., Meyer, H., Schilling, G. (1996). Release and ecological impact of algicidal hydrolysable polyphenols in Myriophyllum spicatum. Phytochemistry, 41, 133-138. http://dx.doi.org/10.1016/0031-9422(95)00598-6

Houston, M. C. (2005). Nutraceuticals, vitamins, antioxidants, and minerals in the prevention and treatment of hypertension. Progress in Cardiovascular Diseases, 47, 396-449. http://dx.doi.org/10.1016/j.pcad.2005.01.004

Kamal, M., Ghaly, A. E., Mahmoud, N., Côté R. (2004). Phytoaccumulation of heavy metals by aquatic plants. Environment International, 29, 1029-1039. http://dx.doi.org/10.1016/S0160-4120(03)00091-6

Kufel, L., Kufel, I. (2002). Chara beds acting as nutrient sinks in shallow lakes-a review. Aquatic Botany, 72, 249-260. http://dx.doi.org/10.1016/S0304-3770(01)00204-2

Li, Z. H., Wang, Q., Ruan, X., Pan, C.-D., \& Jiang, D. A. (2010). Phenolics and plant allelopathy. Molecules, 15, 8933-8952. http://dx.doi.org/10.3390/molecules15128933.

Lichtenthaler, H. K., Wellburn, A. R. (1983). Determinations of total carotenoids and chlorophylls a and b of leaf extracts in different solvents. Biochemical Society Transactions, 11, 591-592. http://dx.doi.org/10.1042/bst0110591 
Mahajan, P., Kaushal, J. (2013). Degradation of congo red dye in aqueous solution by using phytoremediation potential of Chara Vulgaris. Chitkara Chemistry Review, 1, 67-75. http://dspace.chitkara.edu.in/xmlui/handle/1/86

Narain, S., Ojha, C. S. P., Mishra, S. K., Chaube, U. C., Sharma, P. K. (2011). Cadmium and chromium removal by aquatic plant. International Journal of Environmental Sciences, 1, 1297-1304. http://www.ipublishing.co.in/jesvol1no12010/EIJES2081.pdf

Parr, A. J., Bolwell, G. P. (2000). Phenols in the plant and in man. The potential for possible nutritional enhancement of the diet by modifying the phenols content or profile. Journal of the Science of Food and Agriculture, 80, 985-1012. http://dx.doi.org/10.1002/(SICI)1097-0010(20000515)80:7<985::AID-JSFA572>3.0.CO;2-7

Pilon, J., Santamaría, L. (2001). Seasonal acclimation in the photosynthetic and respiratory temperature responses of three submerged freshwater macrophyte species. New Phytologist, 151, 659-670. http://dx.doi.org/10.1046/j.0028-646x.2001.00212.x

Pip, E. (1992). Phenolic compounds in macrophytes from the Lower Nelson River system, Canada. Aquatic Botany, 42, 273-279. http://dx.doi.org/10.1016/0304-3770(92)90028-H

Shaikh, Parveen R., Bhosle, Arjun B. (2011). Bioaccumulation of chromium by aquatic macrophytes Hydrilla sp. and Chara sp. Advances in Applied Science Research, 2, 214-220. http://pelagiaresearchlibrary.com/advances-in-applied-science/vol2-iss1/AASR-2011-2-1-214 -220.pdf

Slinkard, K., Singleton, V. L. (1977). Total phenol analyses: automation and comparison with manual methods. American Journal of Enology and Viticulture. 28, 49-55. http://ajevonline.org/content/28/1/49.full.pdf

Smolders, A. J. P., Vergeer, L. H. T., Van der Velde, G., Roelofs, J. G. M. (2000). Phenolic contents of submerged, emergent, and floating leaves of aquatic and semi-aquatic macrophyte species -why do they differ. Oikos, 91, 307-310. http://dx.doi.org/10.1034/j.1600-0706.2000.910211.x

Spencer, David F., Ksander, G. G. (1994). Phenolic Acid Content of Vegetative Propagules of Potamogeton spp. and Hydrilla verticillata. Journal of Aquatic Plant Management. 32, 71-73. http://www.apms.org/japm/vol32/v32p71.pdf

Whitfield, A. K., Bate, G. C. (2007). A review of information on temporarily open/closed estuaries in the warm and cool temperate biogeographic regions of South Africa, with particular emphasis on the influence of river flow on these systems. Water Research Commission Report, No. 1581/1/07, p. 232.

Zafar, Shoaib M., Muhammad, F., Javed, I., Akhtar, M., Khaliq, T., Aslam, B., Waheed, A., Yasmin, R., Zafar, H. (2013). White mulberry (Morus alba): A brief phytochemical and pharmacological evaluations account. International Journal of Agriculture and Biology. 15, 612-620. http://www.fspublishers.org/published_papers/70394_..pdf 


\section{Copyright Disclaimer}

Copyright for this article is retained by the author(s), with first publication rights granted to the journal.

This is an open-access article distributed under the terms and conditions of the Creative Commons Attribution license (http://creativecommons.org/licenses/by/3.0/). 